\title{
循环经济模式下商业经济生态创新制度建设
}

\author{
梁正 \\ 广西强强碳素股份有限公司 \\ DOI:10.32629/ej.v2i1.82
}

[摘 要] 循环经济(Circular economy), 又可以称之为 “资源循环型经济”, 主要是指以资源节约、循环利用为特征的与环境和 谐相处的经济发展模式,强调资源的节约使用,力求能够降低对生态环境的影响程度。基于此,本文就对循环经济模式下商业经 济生态创新制度建设进行探究, 以期能够建立完善的商业经济生态园,让众多资源得到最优化配置和最高效的使用。

[关键词] 循环经济模式; 商业经济; 生态制度; 创新建设; 作用阐述

在我国社会经济迅速发展的背景下, 对商业经济发展提 出了新的要求, 要求商业经济与自然能够实现和谐发展, 并 获取更多的商业经济。因此, 商业部门展开商业经济生态创 新制度建设工作非常有必要, 本文就对循环经济模式下商业 经济生态创新制度建设的重要作用进行阐述, 并提出具体的 建设途径, 力求能够快速解决商业经济与城市生态环境之间 存在的矛盾问题, 推动商业经济发展。

1 循环经济模式下商业经济生态创新制度建设的作用 阐述

循环经济的思想萌芽最早出现的美国 (于二十世纪六十 年代), 中国出现于九十年代中期, 并将其定义为 “一种以资 源的高效利用和循环利用为核心, 以“减量化、再利用、资 源化' 为原则, 以低消耗、低排放、高效率为基本特征, 符合 可持续发展理念的经济增长模式, 是对 “大量生产、大量消 费、大量废弃” 的传统增长模式的根本变革” [1]。由此循环 经济正式被各大企业所了解, 并被应用。商业部门在循环经 济模式下, 建立商业经济生态创新制度, 具有重要意义, 其最 位主要的意义主要体现在以下几个方面:

一是, 循环经济模式下商业经济生态创新制度建设有利 于促进商业企业的协调发展。现阶段, 商业经济企业数量非 常多, 各个企业的工作内容不同, 负责的活动也存在差异性, 使得企业之间难以对资源进行共享, 且资源配置效率偏低, 无法做到高效率的使用 ${ }^{[2]}$ 。而循环经济模式下商业经济生态 创新制度的建设刚好可以解决此种情况, 让商业经济的各个 企业实现全面协调发展, 各种资源得到最优化配置, 从而在 潜移默化中对资源配置效率进行有效规范, 推动商业经济的 进一步发展。

二是, 循环经济模式下商业经济生态创新制度建设有利 于循环经济的全面发展。城市在发展过程中, 经常会遇到各 式各样的问题, 导致经济效益难以获得提升, 影响到商业生 态经济的发展 ${ }^{[3]}$ 。而循环经济模式下商业经济生态创新制度 建设刚好可以解决此种问题, 在商业发展中融入生态学理论, 并从多方面开展工作, 从而让商业经济实现循环发展, 循环 经济实现全面发展, 意义重大。

三是, 循环经济模式下商业经济生态创新制度建设有利
于解决资源浪费问题。资源浪费问题是企业发展中面临的关 键问题, 对环境建设工作产生一定负面影响 ${ }^{[4]}$ 。而循环经济 模式下商业生态创新制度建设刚好可以解决此种问题, 让 各个企业树立 “企业与企业之间实行循环经济” 的理念, 重点关注资源浪费问题的解决, 确保商业部门发展过程中 能够快速解决生态经济问题, 并形成相互协作的机制, 从而 提高城市生态环境, 实现整个商业经济全面协调可持续发 展的初衰。

四是, 循环经济模式下商业经济生态创新制度建设有利 于提高商业经济发展水平。现阶段, 商业经济在经营发展过 程中, 经常会受到各种因素的影响, 导致商业经济质量和综 合竞争力难以得到有效提升, 影响到行业的可持续发展。而 循环经济模式下商业经济生态创新制度建设刚好可以解决 此种问题, 商业部门在循环经济模式下不断强化生态产业 链, 确保行业能够朝向绿色生态方向发展, 从而在潜移默化 中提高产业经济的发展质量和经济效益, 促进商业经济的 快速发展。

五是, 循环经济模式下商业经济生态创新制度建设有利 于提升我国商业经济发展质量。众所周知, 我国商业部门在 发展过程中, 经常会遇到资源浪费等一系列问题, 导致发展 脚步缓慢, 难以应对市场发展趋势 ${ }^{[5]}$ 。而循环经济模式下商 业经济生态创新制度建设刚好可以解决此问题, 对产生的生 态环境问题需要采取积极有效的补偿措施, 从根本上消除过 度对自然资源消耗的问题, 潜移默化中提升商业经济发展质 量, 与国家可持续发展战略相吻合。

\section{2 可持续循环商业经济模式的详细分析}

众所周知, 商业经济可持续发展离不开物质基础, 因此, 商业部门要想让商业经济实现循环发展, 就需要注重各种因 素的综合性分析工作, 通过分析结果, 进行组合机制构建, 确 保各种资源能够实现最优化配置, 满足商业经济全面协调发 展的需求, 带动行业的整体进步 ${ }^{[6]}$ 。一般情况下, 循环经济可 以划分成三个层次, 且每一个层次都有不同的需求, 以下就 对循环经济的三个层次进行分析, 以供大家了解:

一是, 企业层的清洁消费体系建设分析。将循环经济从 微观层面进行分析, 其主要有企业层的清洁消费体系建设构 
成, 在此阶段, 商业部门要想实现经济的循环发展, 就需要建 立清洁消费科技项目, 并根据项目的具体情况和企业发展走 向, 制定合理的应对措施, 确保能够将各式各样的新技术都 运行到商业经济发展中, 从而可以让商业经济实现全面协调 发展, 稳定带动行业的发展。

二是, 商业部门需要建立完善的生态商业区 ${ }^{[7]}$ 。可持续 循环商业经济模式下, 商业部门要想提高商业经济, 就需要 在发展过程中建立完善的生态上业务, 并确保生态商业区在 发展过程中, 能够实现设计、规划、建设等多项工作, 形成一 种新型的商业经济发展形式。与此同时, 商业部门在构建生 态商业区过程中, 还需要有效结合生态学原理, 将自然生态、 企业发展、消费者等多种因素进行有效融合, 形成互利共生 网络系统, 确保各种活动都能顺利展开, 满足城市发展需求。

三是, 商业部门需要建立微观层次的商业循环经济发展 模式。商业部门在发展过程中会受到各种各样的外界因素影 响, 导致经营过程中会出现各式各样的问题, 影响行业的后 续发展 ${ }^{[8]}$ 。针对此种情况, 商业部门要想实现稳定有序发展, 充分运用可持续循环商业经济模式, 就需要建立微观层次的 商业循环经济发展模式, 对消费环节、流通环节、资源回收 环节等进行有效整合, 然后建设生态创新制度, 从而让商业 经济可以实现循环发展, 带动行业的稳定进步。

\section{3 循环经济模式下商业经济生态创新制度建设的途径} 分析

商业部门要想在循环经济模式下, 顺利建设商业经济生 态创新制度, 就需要严格做到以下几点:

一是, 商业部门需要遵循 “以人为本” 的科学发展观, 让人口、资源、环境相协调, 合理利用自然资源和环境容量, 让经济系统和谐地纳入到自然生态系统的物质循环过程之 中, 确保商业部门能够对各种资源实现高效率利用, 从而提 高商业部门所能够获取的经济效益。

二是, 商业部门需要注重循环经济的发展, 将环境与发 展协调的最高目标相统一, 充分考虑节省资源、提高单位生 产产品对资源的利用率、预防和减少废物的产生, 并注重绿
色设计工作, 确保所生产出的产品都具有环保性, 减少对生 态环境的危害。

三是, 在可持续发展理念和循环经济下, 商业部门需要 转变以往的工作理念, 注重工作人员综合素质的培训工作, 提高每一位工作人员的专业素质和综合素质, 让其能够充分 应对自身工作, 并在工作中发挥出最大价值, 确保能够实现 商业经济持续增长的总体目标。

\section{4 结束语}

总而言之, 商业经济在发展过程中, 建立完善的生态创 新制度是发展的必然趋势, 直接关乎到商业经济发展水平能 否得到有效提升。面对此种情况, 商业部门在发展过程中, 要想让商业经济知名度得到有效扩展, 就需要积极展开商业 经济生态创新制度建设工作, 强化现有的生态产业链, 让产 业经济发展朝向绿色生态方向发展, 在此种情况下, 可以有 效形成循环经济效益, 从而提高生态经济创新管理质量, 让 商业部门实现稳定有序的发展。

\section{[参考文献]}

[1]金丽花.循环经济模式下的商业经济制度创新探讨 [J].企业改革与管理,2017(2):121.

[2]吴音音.浅谈商业经济生态创新在循环经济模式下的 建设与发展[J].财讯,2017(20):65-66.

[3]黄兴.在循环经济视角下对酒店企业绿色管理模式分 析[J]. 商业经济,2015(12):102-104.

[4]丁清旭.我国煤化工工业园区循环经济发展路径及对 策[J].商业经济研究,2015(17):125-126.

[5]刘天舒,李艳梅. 基于生态效率的区域循环经济发展 水平比较[J]. 商业经济研究,2016(8):129-132.

[6]王浩.西部地区绿色物流发展与低碳循环经济的匹配 度研究[J]. 商业经济研究,2016(11):80-82.

[7]郭宏,武星,索贵涁.生态一技术创新支撑区域循环经 济发展效果评价[J].商业经济研究,2016(1):117-118.

[8]林强.推进商业经济新时期创新发展的路径探索 [J]. 消费导刊,2018(26):217. 